Journal Club

Editor's Note: These short, critical reviews of recent papers in the Journal, written exclusively by graduate students or postdoctoral fellows, are intended to summarize the important findings of the paper and provide additional insight and commentary. For more information on the format and purpose of the Journal Club, please see http://www.jneurosci.org/misc/ifa_features.shtml.

\title{
The Influence of Systemic Immune Response and Sleep Modulation on the Secondary Effects of Traumatic Brain Injury in the Rodent Model
}

\author{
(1)Carrie A. Sheeler \\ Section of Neuroadaptation and Protein Metabolism, National Institute of Mental Health, Bethesda, Maryland 20892 \\ Review of Dash et al.
}

In 2010, the US Centers for Disease Control reported 50,000 deaths and 2.5 million hospitalizations linked to traumatic brain injury (TBI). The manifestations of TBI can vary greatly across patients, but they have common mechanistic bases, which are sorted into primary and secondary effects. Primary injury is the direct damage caused by the application of force to the brain, such as the diffuse axonal injury associated with shearing forces. Secondary damage results from the body's response to the initial injury and can include neuroinflammation, herniation, blood-brain barrier (BBB) disruption, white matter degradation, and neuronal loss (Dash et al., 2016; Hay et al., 2015). These internal responses beget longlasting health consequences including sleep disruption (Morawska et al., 2016), increased likelihood for psychiatric diagnosis (Merkel et al., 2016), and greater risk for the development of neurodegenerative disease including dementia and chronic

Received April 29, 2016; revised June 2, 2016; accepted June 5, 2016.

The author thanks Dr. Carolyn Beebe Smith, Dr. Rachel Saré, Matthew Blum, Connor Tribble, and Matthew Peworchik for assistance in the revision of this paper.

This work was supported by the Intramural Research program of the National Institute of Mental Health.

The author declares no competing financial interests.

Correspondence should be addressed to Carrie A. Sheeler, Section of Neuroadaptation and Protein Metabolism, National Institute of Mental Health, Building 10, Room 2D54, 10 Center Drive, Bethesda, MD 20892. E-mail: carrie.sheeler@nih.gov.

DOI:10.1523/JNEUROSCI.1418-16.2016

Copyright $\odot 2016$ the authors $\quad 0270-6474 / 16 / 367341-02 \$ 15.00 / 0$ traumatic encephalopathy (Hay et al., 2015; Li et al., 2016). Despite trends toward safety and awareness, a growing proportion of sports-related injuries in youths is linked to TBI (Coronado et al., 2015); this is concerning because even one instance of moderate or severe TBI can be associated with long-lasting, extensive BBB dysfunction (Hay et al., 2015).

Although many researchers focus on the effect of inflammation on disease progression within the CNS, few investigate the role of peripheral systems in the etiology of TBI. Studies in TBI patients have revealed elevated concentrations of the proinflammatory cytokines interleukin (IL)- 6 and tumor necrosis factor (TNF)- $\alpha$ in circulating plasma, though these increases were far less pronounced than those of CNS cytokine concentrations. This significant difference in cytokine levels between the CNS and the periphery suggested to researchers that disease progression after TBI was almost exclusively the result of inflammatory cascades initiated and maintained within the CNS compartment (Helmy et al., 2011; Roberts et al., 2013). However, intraperitoneal injection of IL- $1 \beta$ and TNF- $\alpha$ in rodents worsens behavioral reflexes, contusion histopathology, and BBB permeability after TBI (Utagawa et al., 2008; Dash et al., 2016). Furthermore, macrophage-produced TNF- $\alpha$ contributes to disruption of the BBB in rodent models of multiple sclerosis, and blockage of TNF- $\alpha$ activity lowers the concentration of immune-reactive cells within the CNS compared with untreated controls (Valentin-Torres et al., 2016). These findings suggest that peripheral macrophage activation and infiltration play a significant role in the regulation and maintenance of the neural immune response.

Recent studies have suggested that the autonomic nervous system, as a regulator of homeostatic processes, modulates peripheral macrophage activation through the activity of the splenic nerve (Martelli et al., 2014). Specifically, nerve terminals in the white pulp of the spleen discharge norepinephrine to activate $\beta$-adrenergic receptors of nearby $\mathrm{T}$ cells. These lymphocytes then release acetylcholine which binds to $\alpha 7$ nicotinic acetylcholine receptors ( $\mathrm{nAChR} \alpha 7)$ on nearby macrophages, suppressing the production of proinflammatory cytokines, including TNF- $\alpha$, and decreasing antibody production in macrophages and B cells (Pereira and Leite, 2016). With this in mind, Dash et al. (2016) examined the effect of $\mathrm{nAChR} \alpha 7$ signaling in the spleen on $\mathrm{BBB}$ permeability and histopathology after TBI. They found that nAChR $\alpha 7$-null mice with induced TBI had significantly higher systemic cytokine levels, amplified M1-type macrophage expression in the dentate gyrus, and increased neutrophil infiltration at the site of injury than wild-type and uninjured controls. Significantly greater staining with Evans Blue Dye, a common assay for BBB permeability, was seen in the brains of $\mathrm{nAChR} \alpha 7$ 
knock-outs after TBI than in controls. This indicated that the BBB degraded to a greater extent in the absence of $\mathrm{nAChR} \alpha 7$ signaling. Injecting the $\mathrm{nAChR} \alpha 7$ agonist PNU-282987 into the spleen ameliorated this effect in wild-type mice and rats, preventing degradation of the BBB and decreasing circulating levels of cytokines when administered after injury. In contrast, administrating the $\mathrm{nAChR} \alpha 7$ antagonist $\alpha$-bungarotoxin after injury significantly increased the permeability of the BBB in wildtype mice.

Given the ubiquity of acetylcholine receptors, Dash et al. (2016) next tested whether these results required splenic $\mathrm{nAChR} \alpha 7$ expression. They removed the spleens from a cohort of rats and separated the rats into three treatment groups (PNU282987, $\alpha$-bungarotoxin, and a saline control) and again measured resultant BBB permeability. The previously seen effects of both treatments disappeared in splenectomized rats. This strongly suggests that BBB integrity after TBI relies on the mediation of the systemic immune response by splenic $\mathrm{nAChR} \alpha 7$ signaling. If future studies correlate $\mathrm{nAChR} \alpha 7$ signaling and BBB maintenance with salvaged cognitive function after TBI, mediation of the systemic immune response by positive allosteric modulation of macrophage nAChR $\alpha 7$ could be a bold new neuroprotective strategy in instances of neural injury.

The beneficial effects of $\mathrm{nAChR} \alpha 7$ activation could extend beyond macrophage modulation into other clinical aspects of TBI. Recent evidence suggests that $\mathrm{nAChR} \alpha 7$ activation in the thalamic reticular nucleus increases both spindle oscillation and the duration of non-REM sleep (Ni et al., 2016). This is particularly interesting given indications that short-term sleep deprivation and the associated increase in slow-wave sleep (SWS) exhibit neuroprotective effects after TBI (Martinez-Vargas et al., 2012). Morawska et al. (2016) found that, after TBI, both sleep-restricted rats and rats in which sleep was induced pharmacologically showed average increases in SWS compared with untreated controls. When cognitive function in these rats was compared with a pre-TBI baseline, neither treatment group exhibited the significant cognitive deficits seen in untreated rats. Immunohistochemical staining of the brains of these rats indicated that amyloid precursor protein (APP) expression was significantly higher in the cortex and hippocampus of control rats compared with those in the treatment groups. Because APP levels in the CNS are associated with diffuse axonal injury, this suggests sleep has a significant neuroprotective effect (Morawska et al., 2016). These beneficial effects of sleep may be due to glymphatic clearing (Iliff et al., 2012) and BBB-stabilizing sleep recovery as noted in cases of neural injury and degeneration (Keaney and Campbell, 2015). This suggests that therapeutic application of an nAChR $\alpha 7$-positive allosteric modulator after TBI could improve TBI outcome through both immune (Dash et al., 2016) and sleep modulation.

The potential lifelong repercussions of TBI are profound. Treatments lessening the severity of TBI's secondary effects could go a long way toward improving long-term prognoses for individuals affected by TBI. Considering the similarities that exist between TBI pathologies and other diseases of neurodegeneration and neuroinflammation, the ongoing study of TBI could be crucial in improving our understanding of human neural health as an interplay between CNS response, sleep, and peripheral immune activation.

\section{References}

Coronado VG, Haileyesus T, Cheng TA, Bell JM, Haarbauer-Krupa J, Lionbarger MR, FloresHerrera J, McGuire LC, Gilchrist J (2015) Trends in sports- and recreation-related traumatic brain injuries treated in US emergency departments: the national electronic injury surveillance system-all injury program (NEISS-AIP) 2001-2012. J Head Trauma Rehabil 30:185-197. CrossRef Medline

Dash PK, Zhao J, Kobori N, Redell JB, Hylin MJ, Hood KN, Moore AN (2016) Activation of alpha 7 cholinergic nicotinic receptors reduce blood-brain barrier permeability following experimental traumatic brain injury. J Neurosci 36:2809-2818. CrossRef Medline

Hay JR, Johnson VE, Young AM, Smith DH, Stewart W (2015) Blood-brain barrier disruption is an early event that may persist for many years after traumatic brain injury in humans. J Neuropathol Exp Neurol 74:11471157. CrossRef Medline

Helmy A, Carpenter KL, Menon DK, Pickard JD, Hutchinson PJ (2011) The cytokine response to human traumatic brain injury: temporal profiles and evidence for cerebral parenchymal production. J Cereb Blood Flow Metab 31:658-670. CrossRef Medline

Iliff JJ, Wang M, Liao Y, Plogg BA, Peng W, Gundersen GA, Benveniste H, Vates GE, Deane R, Goldman SA, Nagelhus EA, Nedergaard M (2012) A paravascular pathway facilitates CSF flow through the brain pa- renchyma and the clearance of interstitial solutes, including amyloid $\beta$. Sci Transl Med 4:147ra111. CrossRef Medline

Keaney J, Campbell M (2015) The dynamic blood-brain barrier. FEBS J 282:4067-4079. CrossRef Medline

Li W, Risacher SL, McAllister TW, Saykin AJ (2016) Traumatic brain injury and age at onset of cognitive impairment in older adults. J Neurol. Advance online publication. Retrieved April 28, 2016. doi:10.1126/scitranslmed. 3003748. Medline

Martelli D, Yao ST, Mancera J, McKinley MJ, McAllen RM (2014) Reflex control of inflammation by the splanchic anti-inflammatory pathway is sustained and independent of anesthesia. Am J Physiol Regul Integr Comp Physiol 307:R1085R1091. CrossRef Medline

Martinez-Vargas M, Rojo FE, Tabla-Ramon E, Navarro-Argüelles H, Ortiz-Lailzon N, Hern'andez-Chávez A, Solis B, Tapía RM, Arredondo AP, Morales-Gomez J, Gonzalez-Rivera R, NavaTalavera K, Navarro L (2012) Sleep deprivation has a neuroprotective role in a traumatic brain injury of the rat. Neurosci Lett 529:118-122. CrossRef Medline

Merkel SF, Razmpour R, Lutton EM, Tallarida CS, Heldt NA, Canella L, Persidsky Y, Rawls SM, Ramirez SH (2016) Adolescent traumatic brain injury induces chronic mesolimbic neuroinflammation with concurrent enhancement in the rewarding effects of cocaine in mice during adulthood. J Neurotrauma. Advance online publication. Retrieved April 11, 2016. doi:10.1089/ neu.2015.4275. Medline

Morawska MM, Büchele F, Moreira CG, Imbach LL, Noain D, Baumann CR (2016) Sleep modulation alleviates axonal damage and $\operatorname{cog}$ nitive decline after rodent traumatic brain injury. J Neurosci 36:3422-3429. CrossRef Medline

Ni KM, Hou XJ, Yang CH, Dong P, Li Y, Zhang Y, Jiang P, Berg DK, Duan S, Li XM (2016) Selectively driving cholinergic fibers optically in the thalamic reticular nucleus promotes sleep. eLife 5:e10382. CrossRef Medline

Pereira MR, Leite PE (2016) The involvement of parasympathetic and sympathetic nerve in the inflammatory reflex. J Cell Physiol 231:18621869. CrossRef Medline

Roberts DJ, Jenne CN, Léger C, Kramer AH, Gallagher CN, Todd S, Parney IF, Doig CJ, Yong VW, Kubes P, Zygun DA (2013) Association between the cerebral inflammatory and matrix metalloproteinase responses after severe traumatic brain injury in humans. J Neurotrauma 30:1727-1736. CrossRef Medline

Utagawa A, Truettner JS, Dietrich WD, Bramlett HM (2008) Systemic inflammation exacerbates behavioral and histopathological consequences of isolated traumatic brain injury in rats. Exp Neurol 211:283-291. CrossRef Medline

Valentin-Torres A, Savarin C, Hinton DR, Phares TW, Bergmann CC, Stohlman SA (2016) Sustained TNF production by central nervous system infiltrating macrophages promotes progressive autoimmune encephalomyelitis. J Neuroinflammation 13:46. CrossRef Medline 